\title{
Productive Method as the Basis for Soft Skills Development in Engineering Foreign Language Education
}

\author{
Olesya Dmitrievna Medvedeva ${ }^{1, *(D)}$ and Anna Vladimirovna Rubtsova ${ }^{2}$ (D) \\ 1 Department of Foreign Languages, Institute of Humanities, Peter the Great St. Petersburg Polytechnic \\ University, 195251 St. Petersburg, Russia \\ 2 Graduate School of Applied Linguistics, Translation and Interpreting, Institute of Humanities, Peter the Great \\ St. Petersburg Polytechnic University, 195251 St. Petersburg, Russia; annarub2011@yandex.ru \\ * Correspondence: medvedeva_od@spbstu.ru
}

Citation: Medvedeva, O.D.;

Rubtsova, A.V. Productive Method as the Basis for Soft Skills Development in Engineering Foreign Language Education. Educ. Sci. 2021, 11, 276. https://doi.org/10.3390/

educsci11060276

Academic Editor: Silvija Markic

Received: 22 April 2021

Accepted: 27 May 2021

Published: 2 June 2021

Publisher's Note: MDPI stays neutral with regard to jurisdictional claims in published maps and institutional affiliations.

Copyright: (c) 2021 by the authors. Licensee MDPI, Basel, Switzerland. This article is an open access article distributed under the terms and conditions of the Creative Commons Attribution (CC BY) license (https:// creativecommons.org/licenses/by/ $4.0 /)$.

\begin{abstract}
The modern world requires engineering specialists with excellent hard skills as well as soft skills that contribute to better communication, creativity, and self-realisation of a person. The authors discovered that modern educational standards are starting to focus on soft skills development, proposing requirements for educational programs that contain competencies covering soft skills. To fulfil such needs, there is the productive method of foreign language teaching that implies interactive technologies and masters foreign language communicative competence and soft skills at once. Therefore, the study aimed at developing a technology of soft skills development in engineering foreign language education using the productive method and checking its effectiveness. The authors designed a questionnaire and investigated engineering students' opinions on a need to develop soft skills, which revealed high relevance of the topic, and the possibility of their development while studying a foreign language, which proved the productive method's prospects. Based on findings received and literature analysed, we implemented case studies, problem-based learning, and essay writing in the technology and designed assessment criteria. Testing of the technology was performed by a pedagogical experiment, where qualitative and quantitative methods were applied. To critically analyse the results, we used Cronbach's alpha, which revealed good reliability of the questionnaire, and $t$-test showed high efficiency of the technology that improved students' soft skills.
\end{abstract}

Keywords: soft skills; productive method; foreign language teaching; engineering students; educational standards; professionally oriented foreign language; EMI

\section{Introduction}

Nowadays, there is a high demand for engineering personnel who obtain not only hard skills, which are theoretical knowledge and practical skills related to a specialty of a person, but also soft skills consisting of communication skills, creative thinking, analytical and managerial skills, and interpersonal skills and qualities. An issue of developing such skills in future engineers arises urgently, as a lot of scientists highlight the relevance of soft skills development according to plenty of surveys studying employers' requirements for employees [1-4]. However, sometimes there is a gap between the employers' requirements presented in their job advertisements and really demanded skills, as well as a huge variety of soft skills components proposed by scientists and lack of focus on development of soft skills within higher education. For example, scientists reveal how much training at the university contributed to the formation of these skills and come to the following conclusions: discrepancy between the significance of soft skills for graduates and their formation is more than $10 \%$; activities carried out by the university to adapt and socialize the personality of students contributed to the formation of only basic communication skills; only $10 \%$ of the study time in universities is devoted to the development of soft skills [2,5-7]. 
All this confirms the fact that currently, training at the university level is more aimed at the development of professional knowledge and hard skills. As a result, higher school teachers do not exactly understand which soft skills they need to develop in their students and how to do it so as to fulfil employers' and societal needs. This is especially of high interest for Russian educators, as the topic of soft skills development within Russian higher education is now on the top among researchers. Therefore, there is a need to clarify the concept of soft skills and find useful methods of their development within the higher education.

As long as most scientists consider communication skills and creative thinking basic components of soft skills [2,8-12], engineering foreign language education can allow teachers to develop students' soft skills with the use of communicative and interactive tasks, which can be implemented within a productive method of teaching a foreign language. The productive method is the method of teaching the foreign language that involves usage of various interactive teaching technologies, electronic educational resources and is aimed at advancing not only foreign language communicative competence, but also interpersonal skills and personal qualities of engineering students [13], which are also components of soft skills. According to A. Rubtsova, D. Byleva, and other scientists, the productive method implies organization of the educational process considering professional and socio-cultural situations, in which students learn to solve specific practical, research, organizational and communicative tasks, thereby gaining personal experience of self-determination and self-realization. Moreover, the productive method also provides an opportunity to develop students' skills when working independently in an online format $[13,14]$.

The productive method can be applied in engineering foreign language education using the following interactive teaching technologies: case studies [15], a teaching technology "portfolio" [16], problem-based learning [8,11,17], discussions and debates, role-playing games, a project method, written tasks related to the future professional activities of students $[18,19]$, gamification, storytelling, situational learning $[20,21]$ and collaborative learning [22,23]. Following the findings of the scientists, we can conclude that the most effective productive technologies for the development of soft skills in engineering foreign language education include the following: (1) case studies; (2) problem-based learning; and (3) essay writing.

First, I. Zueva considers case studies to be the most effective technology to develop soft skills, which the author divides into practical, training and research cases, involving engineering students in research and professional activities through a professionally oriented foreign language. With the use of this technology, the students apply theoretical knowledge of phenomena included in their future profession and use their creativity to solve professional tasks set by the teacher, therefore developing their search and analytical abilities, information presentation skills and also increasing the level of foreign language communicative competence [15]. The process of solving cases includes the following activities: search for feedback, self-learning and learning from the experience of others; solving special tasks that develop certain competencies and eliminate shortcomings; inclusion in the study of the material through its presentation in the form of a related story by identifying its emotional and personal significance; self-development in the process of work [24].

The second useful productive technology is problem-based learning which shows its effectiveness in experiments made by different researchers [17,25]. In problem-based learning, students are offered a certain situation related to their professional activities, for which it is necessary to prepare a solution and present it in the form of a presentation. In a small group, students independently distribute the roles and the front of work among themselves, which consists of studying the theoretical material on the topic, developing ways to solve the proposed problem, discussing and describing the chosen solution, and ultimately presenting the entire result to other classmates. At the same time, without the use of soft skills and proper interaction, the problem cannot be successfully solved, since each of the group members is responsible not only for their work, but also for the 
final result [8]. While finding the solution to the problem, students develop their soft skills, which include creativity, interpersonal qualities, teamwork skills, leadership skills, self-regulation, and time management skills $[11,26]$. Problem-based learning is a more complicated and broader activity in comparison to the case study and requires more time for preparation and solving the problem.

Finally, soft skills imply possessing not only oral, but also written communication skills that can be advanced with the use of essay writing related to the future professional activities of students [18]. Writing composes of not just knowing the writing strategies for various types of essays, spelling, grammar, and lexical rules; the writing process involves using and developing search and analytical skills, planning skills, and creative and critical thinking. Therefore, writing is also regarded as a productive technique to master soft skills, which are needed for a specialist to be able to conduct business correspondence, prepare written reports and just chat online with colleagues to discuss multiple ideas $[14,27,28]$. Writing tasks for engineers should include a situation or a problem to solve that will create a challenge for them and motivate them to generate new ideas or innovate existing ones using their creativity and other soft skills [29,30]. Moreover, a written task can be made in an online format as information and communication technologies now can simplify both the process of writing, developing technology and numeracy skills of students, and teacher's evaluation of the work, helping them adapt to educational innovations [31,32].

Thus, by developing engineering students' soft skills within foreign language education, we can master their creativity, which is as important as hard skills due to specifics of engineers' professional activities. Engineers need to use creative thinking to invent new technologies for society and make breakthroughs to better people's lives. Having reviewed the literature, we examined how certain interactive technologies can be applied for soft skills development in a higher school, but there was no correlation between the productive method, foreign language teaching and soft skills development, therefore, our research question is to check whether the productive method can be useful for soft skills development in engineering foreign language education. Consequently, the main purpose of our research is to develop a technology of soft skills development based on the productive method which will be applied in engineering foreign language education. To achieve this goal, we had to complete the following tasks:

1. To study the scientific literature on the topic of the productive method as a basis for soft skills development in engineering foreign language education;

2. To analyse soft skills implementation in the system of engineering foreign language education;

3. To carry out a survey studying engineering students' opinions on the need to develop soft skills and a possibility of their development while learning the foreign language;

4. To develop components of the technology of engineering students' soft skills development based on the productive method;

5. To conduct experimental training and perform statistical analyses of the obtained data in order to prove the efficiency of the technology described in the paper.

\section{Materials and Methods}

The information for the research was sourced from the review and analysis of the literature concerning the productive method for teaching a foreign language, soft skills development, and usage of productive activities to advance soft skills. For this purpose, diverse scientific papers, articles, and books were scanned. Moreover, we studied several Russian educational standards and CEFR to discover the implementation of soft skills in such acts.

The experimental training was conducted using empirical methods which included the following stages.

1. Conducting a survey: (1) designing a questionnaire to investigate students' opinions on a need to develop soft skills and a possibility of their development while studying a foreign language; (2) carrying out the survey with the use of the designed questionnaire 
among engineering students of the 1st-3rd years of education in Peter the Great St. Petersburg Polytechnic University (SPbPU), Russia. All 192 respondents volunteered to take part in the survey; they were informed about the objective of the study and guaranteed anonymity; (3) finding out the reliability of the questionnaire with the use of SPSS program and Cronbach's alpha coefficient. The detailed description of design and validation of the survey is presented in the Section 3.2.

2. Designing the components of the technology using the productive method for developing soft skills in engineering foreign language education. For this purpose, we propose to apply the case study, problem-based learning, and essay writing as the most effective productive activities for soft skills development. Furthermore, we designed assessment criteria for evaluating completion of these tasks and mastering all groups of soft skills, as well as stages of organizing productive activities in engineering foreign language education for the experiment.

3. Quantitative and qualitative research methods: a pedagogical experiment in the experimental group of students. During the preliminary stage of the experiment, we tested the level of students' soft skills development using the questionnaire developed by the Laboratory of soft skills competencies of Southern Federal University (Rostov-onDon, Russia) uploaded into the Moodle, which is detailed in Section 3.3. The initial stage consisted of monitoring the development of soft skills of the participants with the use of the case study, while the intermediate stage was composed of implementing and evaluating the problem-based learning of the students; both stages included the participants' peer assessment and the teacher's evaluation of the students' progress using the designed assessment criteria. At the final stage, the essay writing was implemented to master soft skills, where our assessment criteria and the IELTS Writing band descriptors were used for evaluation. Eventually, we examined the development of soft skills of the students of both the experimental and control groups to conduct further analyses.

4. The quantitative research method: carrying out the data analysis using the descriptive statistical method to critically analyse the findings received. For this purpose, we used the SPSS program version 26.0, where T-statistics was conducted to find out statistical significance between results obtained during initial and final stages of the experiment.

The study took place at Peter the Great St. Petersburg Polytechnic University (SPbPU), Russia. The survey involved 192 engineering students studying for a Bachelor's degree in the 1st, 2nd and 3rd years. The participants were all Russian students aged 17-21; 43 of them were female and 149 were male. The experimental training included the engineering students of the 2 nd year of education studying the Professionally oriented English language course. Twenty-three students of the experimental group and 22 respondents of the control group, aged 18-20, volunteered to take part in the experiment; they were informed about the objective of the study and guaranteed anonymity.

\section{Results}

\subsection{Soft Skills Implementation in Educational Standards}

Based on the analysis of scientific literature, we came to the conclusion that soft skills are a set of supra-professional skills and personal qualities that contribute to a person's successful interaction in society, effective implementation of hard skills, and achieving success in professional activities. We examined the soft skills components and found out that soft skills include communication skills (teamwork, negotiation, oral and written communication, oratory skills, etc.), management skills (management and organizational skills, critical thinking skills, time allocation, leadership skills, adaptability, responsibility, creativity, etc.) and professional skills (skills of using modern technologies, numeracy skills, hard work, etc.) [33].

To implement the development of soft skills within higher education, it is necessary to base it not only on the typology of soft skills, but also on the requirements for the results of studying higher education programs, which in Russia are formulated in the Federal State Educational Standard of Higher Education. Therefore, we decided to study 
the Federal State Educational Standard of Higher Education developed for 42 technical specialties, within the framework of which Bachelor's degree training is carried out at Peter the Great St. Petersburg Polytechnic University (SPbPU) [34]. It was revealed that as a result of mastering the Bachelor's degree program, graduates should develop the following multipurpose and professional competencies connected to soft skills (Table 1). Interpretation of the findings is presented in the Discussion.

Table 1. Soft skills implementation in the Federal State Educational Standard of Higher Education.

\begin{tabular}{|c|c|c|c|c|}
\hline Soft Skills & & Multipurpose Competencies ${ }^{1}$ & & Professional Competencies ${ }^{1}$ \\
\hline \multirow{3}{*}{ Communication skills } & - & $\begin{array}{l}\text { An ability for oral and written } \\
\text { communication in Russian and foreign } \\
\text { languages; an ability to perceive } \\
\text { intercultural diversification of society; }\end{array}$ & - & \multirow[t]{3}{*}{$\begin{array}{l}\text { An ability to apply knowledge of a foreign } \\
\text { language in professional activities. }\end{array}$} \\
\hline & - & $\begin{array}{l}\text { An ability to communicate in a foreign } \\
\text { language so as to work with the } \\
\text { international community; }\end{array}$ & & \\
\hline & - & $\begin{array}{l}\text { An ability for social interaction and } \\
\text { self-realisation in a team. }\end{array}$ & & \\
\hline \multirow{2}{*}{ Management skills } & - & $\begin{array}{l}\text { An ability to manage tasks and choose } \\
\text { appropriate ways of solving problems; }\end{array}$ & - & \multirow{2}{*}{$\begin{array}{l}\text { An ability to make decisions and choose } \\
\text { appropriate means and technologies in } \\
\text { professional activities; } \\
\text { An ability for management of work } \\
\text { and staff. }\end{array}$} \\
\hline & - & $\begin{array}{l}\text { An ability for time-management, } \\
\text { self-development, and lifelong } \\
\text { learning. }\end{array}$ & - & \\
\hline \multirow{2}{*}{ Professional skills } & - & $\begin{array}{l}\text { An ability to search for and critically } \\
\text { analyse information. }\end{array}$ & - & $\begin{array}{l}\text { An ability to solve professional tasks using } \\
\text { information and communication } \\
\text { technologies; }\end{array}$ \\
\hline & & & - & $\begin{array}{l}\text { An ability to search for, store, manipulate } \\
\text { and analyse information using information } \\
\text { and communication technologies. }\end{array}$ \\
\hline
\end{tabular}

${ }^{1}$ Federal State Educational Standard of Higher Education.

3.2. Investigation of Students' Opinions on the Need to Develop Soft Skills and the Possibility of Their Development While Studying a Foreign Language

Further, we needed to ask engineering students whether they need soft skills and understand how they can develop them within higher education. This is essential due to the following issues: (1) Russian higher education is only starting to focus on students' soft skills development, and we wanted to know whether engineering students of SPbPU are aware of such a tendency; (2) high school teachers do not exactly understand which and how academic disciplines can be used for soft skills development, and we wanted to ask the students to define the most appropriate disciplines for soft skills development in their opinion so that the teachers could start this process during their teaching. For that reason, the initial stage of the pedagogical experiment included a questionnaire on the topic of studying engineering students' opinions on the need to develop soft skills and the possibility of their development while learning a foreign language. The survey was carried out among engineering students of the 1st-3rd year of education in SPbPU in Russian. There were 90 participants of the 1 st year (46.9\%), 83 participants of the 2 nd year $(43.2 \%)$, and 19 respondents of the 3rd year of education (9.9\%). The questionnaire consists of 9 questions where students had to choose the most appropriate option for them expressing their opinion on the topics covered in the questions, and 1 question to choose their year of education. Options for choosing are presented in a Likert scale where " 1 " means "completely disagree" and "5" means "completely agree". To prove 
the questionnaire's validity, we conducted the reliability analysis using Cronbach's alpha coefficient and SPSS version 26.0. The reliability analysis with $\alpha=0.781, \alpha$ based on standardized items $=0.790$ and number of items $=9$ shows that the items have relatively high internal consistency which means that the questionnaire is valid.

The results of the survey are shown in Table 2 where the questions and a number of students who chose this or that option are presented. The interpretation of the findings is performed in the Discussion.

Table 2. Investigation of students' opinions on the need to develop soft skills and the possibility of their development while studying a foreign language.

\begin{tabular}{|c|c|c|c|c|c|}
\hline Questions/Answers & 1 & 2 & 3 & 4 & 5 \\
\hline $\begin{array}{l}\text { 1. I know what soft skills are and how much they are in } \\
\text { demand in modern professional activities. }\end{array}$ & 14 & 16 & 35 & 53 & 74 \\
\hline $\begin{array}{l}\text { 2. I believe that the possession of soft skills, along with } \\
\text { professional ones, will be my advantage when applying } \\
\text { for a job. }\end{array}$ & 2 & 7 & 26 & 65 & 92 \\
\hline $\begin{array}{l}\text { 3. I believe that the possession of soft skills, along with } \\
\text { professional ones, can contribute to easier achievement } \\
\text { of success in my professional activity and career. }\end{array}$ & 4 & 7 & 21 & 55 & 105 \\
\hline $\begin{array}{l}\text { 4. I believe that the development of soft skills should } \\
\text { take place during the study at the university. }\end{array}$ & 5 & 10 & 45 & 69 & 63 \\
\hline $\begin{array}{l}\text { 5. I believe that technical disciplines contribute to the } \\
\text { development of my soft skills. }\end{array}$ & 7 & 24 & 59 & 52 & 50 \\
\hline $\begin{array}{l}\text { 6. I believe that social and humanitarian disciplines, } \\
\text { including a foreign language, contribute to the } \\
\text { development of my soft skills. }\end{array}$ & 5 & 14 & 39 & 76 & 58 \\
\hline $\begin{array}{l}\text { 7. I believe that participation in dialogues and } \\
\text { discussions while studying the discipline "Foreign } \\
\text { language" contributes to the development of my } \\
\text { communication skills. }\end{array}$ & 10 & 16 & 32 & 47 & 87 \\
\hline $\begin{array}{l}\text { 8. I believe that preparation and presentation of projects, } \\
\text { implementation of cases, and participation in }\end{array}$ & & & & & \\
\hline $\begin{array}{l}\text { role-playing games while studying the discipline } \\
\text { "Foreign Language" contribute to the development of } \\
\text { my manaement skills. }\end{array}$ & 11 & 14 & 33 & 63 & 71 \\
\hline $\begin{array}{l}\text { 9. I believe that performing various computer tests and } \\
\text { online tasks within the discipline "Foreign Language" } \\
\text { contributes to the development of my professional skills. }\end{array}$ & 29 & 39 & 44 & 45 & 36 \\
\hline
\end{tabular}

\subsection{Usage of the Productive Method for Soft Skills Development}

After carrying out the survey, we decided to design the technology of soft skills development, which includes case studies, problem-based learning, and essay writing as basic productive methods within engineering foreign language education for soft skills development. Table 3 presents stages of organizing productive activities that are proposed by the authors based on the literature review. 
Table 3. Stages of organizing productive activities within the technology of soft skills development in engineering foreign language education.

\begin{tabular}{|c|c|c|c|}
\hline Stages/Tasks & Case Study & Problem-Based Learning & Essay Writing \\
\hline Initial stage & $\begin{array}{l}\text { 1. Giving instructions for the task; } \\
\text { 2. Announcing assessment criteria. }\end{array}$ & $\begin{array}{l}\text { 1. Giving instructions for the task; } \\
\text { 2. Announcing assessment criteria; } \\
\text { 3. Providing students with } \\
\text { information connected to their } \\
\text { specialty and needed for solving the } \\
\text { problem using EMI; } \\
\text { 4. Distribution of responsibilities } \\
\text { within the group. }\end{array}$ & $\begin{array}{l}\text { 1. Giving instructions for the task; } \\
\text { 2. Announcing assessment criteria; } \\
\text { 3. Providing students with } \\
\text { information connected to their } \\
\text { specialty and needed for writing an } \\
\text { essay using EMI. }\end{array}$ \\
\hline Intermediate stage & $\begin{array}{l}\text { 1. Teacher's monitoring the process of } \\
\text { solving the case. }\end{array}$ & $\begin{array}{l}\text { 1. Teacher's monitoring the process of } \\
\text { solving the problem; } \\
\text { 2. Teacher's assistance if needed; } \\
\text { 3. Redistribution of responsibilities if } \\
\text { needed; } \\
\text { 4. Students' presenting intermediate } \\
\text { results. }\end{array}$ & $\begin{array}{l}\text { 1. Teacher's monitoring the process of } \\
\text { writing the essay; } \\
\text { 2. Teacher's assistance if needed. }\end{array}$ \\
\hline Final stage & $\begin{array}{l}\text { 1. Discussing solutions provided; } \\
\text { 2. Peer assessment; } \\
\text { 3. Teacher's assessment. }\end{array}$ & $\begin{array}{l}\text { 1. Students' presenting final results to } \\
\text { other classmates; } \\
\text { 2. Peer assessment; } \\
\text { 3. Teacher's assessment. }\end{array}$ & $\begin{array}{l}\text { 1. Students' handing in the essays; } \\
\text { 2. Teacher's assessment. }\end{array}$ \\
\hline
\end{tabular}

The following stage of the pedagogical experiment took place in SPbPU among two groups of engineering students ( 23 participants of the experimental group and 22 participants of the control group) of the 2nd year of education, who studied the Professionally oriented English language course, where we were able to use the EMI concept to provide the students with essential information connected to their professional disciplines while setting tasks for the activities used. In Table 4, we show which soft skills can be mastered with the use of these three productive tasks based on the literature review.

Table 4. Soft skills development with the use of productive tasks.

\begin{tabular}{|c|c|c|c|}
\hline Tasks/Soft Skills & Communication Skills & Management Skills & Professional Skills \\
\hline Case study & $\begin{array}{l}\text { Communication skills } \\
\text { Foreign language communicative } \\
\text { competence } \\
\text { Interpersonal skills } \\
\text { Negotiation skills } \\
\text { Teamwork skills }\end{array}$ & $\begin{array}{c}\text { Change management } \\
\text { Creativity } \\
\text { Critical thinking } \\
\text { Decision making skills } \\
\text { Initiative } \\
\text { Leadership skills } \\
\text { Management skills } \\
\text { Organisational skills } \\
\text { Problem-solving skills } \\
\text { Self-development } \\
\text { Self-management } \\
\text { Working under pressure }\end{array}$ & Professional skills \\
\hline Problem-based learning & $\begin{array}{c}\text { Communication skills } \\
\text { Foreign language communicative } \\
\text { competence } \\
\text { Interpersonal skills } \\
\text { Negotiation skills } \\
\text { Public speaking skills } \\
\text { Teamwork skills }\end{array}$ & $\begin{array}{c}\text { Change management } \\
\text { Creativity } \\
\text { Critical thinking } \\
\text { Decision making skills } \\
\text { Emotional thinking } \\
\text { Initiative } \\
\text { Leadership skills } \\
\text { Management skills } \\
\text { Organisational skills } \\
\text { Problem-solving skills } \\
\text { Self-confidence } \\
\text { Self-development } \\
\text { Self-management } \\
\text { Time management skills } \\
\text { Working under pressure }\end{array}$ & Professional skills \\
\hline
\end{tabular}


Table 4. Cont

\begin{tabular}{|c|c|c|c|}
\hline Tasks/Soft Skills & Communication Skills & Management Skills & Professional Skills \\
\hline \multirow{8}{*}{ Essay writing } & $\begin{array}{l}\text { Foreign language communicative } \\
\text { competence }\end{array}$ & Creativity & Numeracy skills \\
\hline & Writing skills & Critical thinking & Professional skills \\
\hline & & Decision making skills & Technology skills \\
\hline & & Planning skills & \\
\hline & & Problem-solving skills & \\
\hline & & Self-development & \\
\hline & & Self-management & \\
\hline & & Time-management skills & \\
\hline
\end{tabular}

To analyse soft skills development during and after completing the productive tasks, we designed assessment criteria for peer and teacher's assessment, which are presented in Figure 1. For evaluation of the essay, the teacher used the blocks for assessing managements and professional skills from the following assessment criteria and also IELTS Writing band descriptors for evaluating writing skills.

\begin{tabular}{|l|l|}
\hline \multicolumn{2}{|c|}{ Student assessment form } \\
Evaluate the degree of manifestation of personal qualities and soft skills of your interlocutors during the \\
productive task on a scale from 1 to 5, where "1" - wasn't manifested at all, "5" - was fully manifested.
\end{tabular}

Figure 1. Assessment criteria for productive tasks.

The control of soft skills development is based on the results of the assessment of each student by the teacher and groupmates independently, where the maximum score showing effective soft skills development and the best completion of the task is 63, where 0-37 points mean the rating «unsatisfactory», 38-47 points-《satisfactory», 48-56 points- «good», and 57-63 points-《excellent». 
Evaluation of the essay writing task is completed only by the teacher who uses the blocks for assessing management and professional skills from the assessment criteria, which can give the maximum score of 42, and IELTS Writing band descriptors, which give up to 9 points for writing skills. Therefore, effective development of soft skills is shown by receiving the maximum of 51 points, where $0-30$ points mean the rating «unsatisfactory», 31-37 points-《satisfactory», 38-45 points-《good», and 46-51 points-《excellent».

After using the productive tasks in the experimental group, we received the average score of the students' soft skills development, which is shown in Table 5.

Table 5. The average score of the students' soft skills development after using the productive activities.

\begin{tabular}{cccc}
\hline & Case Study & Problem-Based Learning & Essay Writing \\
\hline The average score & 39 & 51 & 46 \\
\hline
\end{tabular}

Moreover, to compare and analyse the level of students' soft skills development both in the experimental and control groups we used the questionnaire made by the Laboratory of soft skills competencies of Southern Federal University. This survey consists of 55 questions describing the manifestations of 11 soft skill competencies, and its purpose is to form students' understanding of the essence of competencies and the areas that they need to focus on to develop their soft skills. The test is assessed using the following scale: 0-14 points-low level, 15-22 points-middle level, and 23 and more points-high level of soft skills development. The results of the experiment are presented in Figure 2.

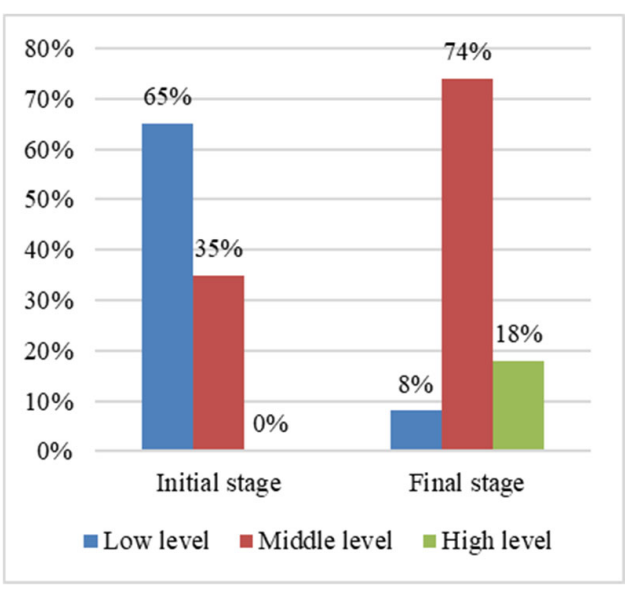

(a)

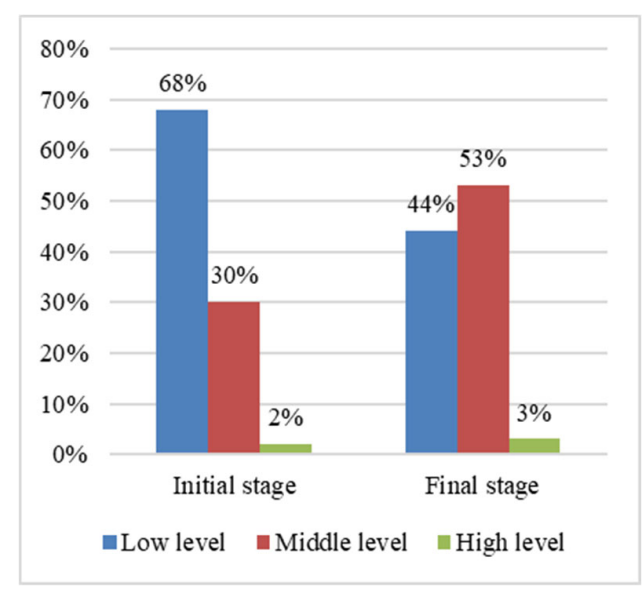

(b)

Figure 2. Levels of students' soft skills development at the initial and final stages of the experiment: (a) In the experimental group; (b) in the control group.

\section{Discussion}

The initial stage of our research consisted of analysing the soft skills implementation in the educational standards, namely, the Federal State Educational Standard of Higher Education in Russia, a curriculum of the Bachelor's program in physics, and the CEFR. Firstly, having analysed the Federal State Educational Standard of Higher Education, we see that Russian higher education is focused on the development of all components of soft skills, which demonstrates orientation of the modern approach to organisation of the educational process in Russia to the development of soft skills. Hence, the soft skills of students can be advanced while receiving their higher education.

Further, we decided to investigate academic disciplines taught in engineering specialties of higher education in Russia and the possibility of developing soft skills in the process of studying them on the example of the curriculum of the Bachelor's program in physics. Based on the data provided in the curriculum, only $40 \%$ of the academic time is allocated 
for lecture-type classes, respectively, it is necessary to analyse academic disciplines of a practical nature. Among these disciplines, we found the disciplines of mathematical, physical, natural-science modules and the module of profile orientation, which are aimed at obtaining and developing fundamental knowledge and skills that relate to professional skills in a particular field (hard skills), respectively, these disciplines are not aimed at developing soft skills, and the educational process within these disciplines does not always allow the use of interactive pedagogical technologies that contribute to the development of soft skills. At the same time, it should be noted that there is an information technology module that provides an opportunity to develop professional skills that are included in the typology of soft skills, as well as a foreign language learning module that contributes to the development of communication and management skills. Thus, it is worth noting the importance of presence of the foreign language learning module that possesses tools, approaches, and teaching methods that need to be applied to develop soft skills.

Moreover, a professionally oriented foreign language course taught at the university allows students to develop their professional skills by means of a foreign language. To reach this goal, the concept of English-medium instruction (EMI) can be used, which has become the subject of close study recently. EMI considers a foreign language as a means of teaching various disciplines. Scientists from different countries emphasise advantages of using EMI in education, showing that this concept contributes to internationalisation of the society, helps in the implementation of academic mobility, and most importantly provides an opportunity for the development of communication and management skills, creating conditions for active interaction of students. However, EMI is an insufficiently studied phenomenon and has several shortcomings identified by researchers, which are as follows: a low level of foreign language proficiency does not allow students to fully assimilate the material on the taught discipline; the low academic performance of students in the discipline with EMI demotivates them to learn the language; currently a small number of high-quality manuals and courses using EMI are presented [35-37]. Nevertheless, this concept is worth further consideration and implementation in the system of engineering personnel training, as it can contribute to the development of soft skills while learning a foreign language.

Speaking about the assessment of soft skills development in a foreign language in the framework of studying foreign language modules at the university, it is necessary to consider the CEFR and the implementation of soft skills in it. The CEFR is a generally accepted system of foreign language proficiency, which includes a description of the competencies that a student must demonstrate by mastering a particular level of a foreign language. In addition to describing well-known communicative competencies, plurilinguistic and pluricultural competencies, the standard describes aspects of language and communication strategies. In the new version of the standard, published in 2020, the authors expanded the descriptors of some competencies and described mediation skills in more detail, thereby emphasizing the need to develop the skills of transmitting information through the interlocutor. At the same time, mediation is presented as a type of speech activity that needs to be taught, and as a communication strategy with which you can learn aspects of the language [38].

In addition to mediation, the standard presents new descriptors of interactive actions and strategies in the framework of language learning, which confirms the relevance of the development of soft skills. In the context of interactive activities, the student must possess the skills of oral interaction (understanding the interlocutor, communication, conducting formal and informal discussions, purposeful interaction, in-formation exchange, receiving goods and services, interviewing and interviewing skills, using telecommunications), written interaction (correspondence skills, ability to write notes, messages, fill in forms), as well as the authors highlight online interaction, which combines the skills of oral and written interaction in the online space and the skills of targeted online cooperation and conducting transactions. Interactive strategies include changing communication roles, interacting with the other person, and being able to ask the other person for an explanation. 
Moreover, this standard emphasizes that inter-personal interaction is the source of language and the basis of learning in general [38].

Therefore, it can be seen that not only employers pay attention to the necessity of possessing soft skills, but also modern Russian educational standards and international educational standards of language learning are starting to change their attitude towards soft skills, and now they implement competencies and descriptors for their assessment focusing on soft skills. Thus, the soft skills development must be performed within the higher education and foreign language learning.

Consequently, the first stage of our experiment included designing the survey on the investigation of the students' opinions on the need to develop the soft skills and the possibility of their development while studying the foreign language, which is presented in Table 2. Having conducted the survey, we can conclude that most of the students $(27.6 \%$ agreed and $38.5 \%$ completely agreed) are aware of the relevance of soft skills development. The vast majority of respondents think that soft skills are necessary to possess when applying for a job (33.9\% agreed and $47.9 \%$ completely agreed) and to have prospects for rapid career progress (28.6\% agreed and $54.7 \%$ completely agreed). Therefore, we see confirmation of scientists' research regarding the importance of soft skills development. Furthermore, a lot of engineering students think that they should develop their soft skills while getting higher education (35.9\% agreed and $32.8 \%$ completely agreed). This is the confirmation of the demand for constructing methods for soft skills development with the use of techniques that academic disciplines can provide teachers with.

Speaking about the academic disciplines that can contribute to soft skills development, plenty of students declared that they are not sure if the technical disciplines help develop their soft skills (30.7\%) and that the social and humanitarian disciplines, including foreign languages, contribute to it (39.6\% agreed and $30.2 \%$ completely agreed), thus sustaining the results of our analysis of the disciplines taught in engineering specialties of higher education in Russia. Nevertheless, quite a huge amount of the respondents agreed (27.1\%) and completely agreed $(26 \%)$ with the statement about the technical disciplines that can testify possible implementation of ways of soft skills development which teachers of the technical disciplines must use. Moreover, we suppose that the technical disciplines can facilitate advancing the group of professional skills within soft skills, which include numeracy skills, technology skills, and some personal qualities connected to the group of management skills.

Regarding engineering foreign language education, the students proved our notion of effectiveness of productive technologies usage for mastering soft skills. Most of the respondents positively reflected on the usage of dialogues and discussions in the foreign language for communication skills development (24.5\% agreed and $45.3 \%$ completely agreed) and the usage of a project method, solving cases and role-playing for management skills development (32.8\% agreed and 37\% completely agreed). However, many participants suppose that computer tests and online tasks cannot conduce developing the group of professional skills within soft skills (22.9\% were not sure, $20.3 \%$ disagreed and $14.6 \%$ completely disagreed), therefore, we conclude that the computer tests can be used just to monitor students' progress of the level of foreign language communicative competence and we suppose that online tasks, such as web-quests or tasks for finding and analysing information, are not popular enough in Russian foreign language training, as a result, the students are not acquainted with these types of educational technologies and cannot express their opinion on this issue. Furthermore, as it was mentioned before, the technical disciplines can help develop such soft skills.

Consequently, we designed the technology of soft skills development in engineering foreign language education using the productive method, which includes three stages of applying the case study, problem-based learning, and essay writing, and which is shown in Table 3. For the evaluation of completing these tasks and mastering all groups of soft skills by the students, we developed the assessment criteria that are presented in Table 4. All this was used in the experimental training of the experimental group of the 2nd year 
engineering students, who studied the Professionally oriented English language course. After implementing the technology, we got the average score of the students' soft skills development, which is shown in Table 5.

Having analysed the findings, we can conclude that after completing the case study, the students on average got a satisfactory rating (39 out of 63) for their soft skills development, which means that they were not quite ready to use their communication, management, and professional skills. After applying problem-based learning, the results improved with a good rating (51 out of 63), showing the ability of students to implement and develop their soft skills. The findings of the essay writing revealed their excellent rating (46 out of 51) of soft skills development, proving that they started to apply and advance their soft skills effectively.

Furthermore, we applied the questionnaire made by the Laboratory of soft skills competencies of Southern Federal University to examine the level of soft skills development among the students of both the experimental and control groups. The results are presented in Figure 2. As can be seen from the diagrams, at the initial stage of the experiment levels of soft skills development were almost the same in both experimental and control groups, where the largest group of students ( $65 \%$ and $68 \%$, respectively) had a low level of soft skill development, and a third of students (35\% and $30 \%$, respectively) had a middle level, while scarcely anyone ( $0 \%$ and $3 \%$, respectively) had a high level. Furthermore, we conducted T-statistic for independent samples and discovered that there were no statistically significant differences between the two groups of students in terms of their level of soft skills development as the overall $p$-value was more than the critical $p$-value $(p=0.689, \alpha=0.05)$.

After using the productive method for soft skills development in the experimental group, we asked the students of both groups to take part in the same survey again to trace dynamics in soft skills levels. According to the results presented in the diagram, the final stage of the experiment shows that the low level was demonstrated by only $8 \%$ of the students from the experimental group, while in the control group, the findings did not completely change in comparison with the initial stage of the experiment $(44 \%)$. The majority of the participants in both groups had the middle level of soft skills, but the difference in the dynamics was big enough ( $74 \%$ of the students in the experimental group and $53 \%$ in the control group). The high level was possessed by $18 \%$ of the respondents from the experimental group showing the positive dynamics, and it was almost the same in the control group at the initial and final stages (3\%).

To contend with the data received, we used the T-statistic for independent samples and discovered that there were statistically significant differences between two groups of students in terms of their level of soft skills development at the final stage of the research as the overall $p$-value was less than the critical $p$-value $(p=0.001, \alpha=0.05)$. Thus, the statistics proved the effectiveness of the productive method for advancing soft skills.

Having conducted the experiment, we found that soft skills can be mastered using the productive method of foreign language teaching, where the case study, problem-based learning and essay writing proved to be useful. Consequently, utilising the proposed technology by the foreign language teachers can lead to (1) mastering soft skills and foreign language communicative competence at once; (2) cut in differences between the employers' requirements and skills the future engineers possess; (3) more focusing of the university education on soft skills development.

\section{Conclusions}

Soft skills development is urgently relevant in today's society. Based on the literature review, we see that not only researchers notice it, but also educational standards have begun to focus on soft skills development, proposing official requirements for Bachelor's degree programs that contain competencies covering soft skills, as well as descriptors for their monitoring, leading to a possible decrease in the discrepancy between the requirements of the employers and the skills that future engineers will possess developing them at the 
university. Moreover, engineering students show their awareness and interest in soft skills development, which was proven through the questionnaire designed by the authors and used in the survey of 192 engineering students of Peter the Great St. Petersburg Polytechnic University, Russia. The results of the survey justify that engineering foreign language education has effective means for students' soft skills development. The designed survey can be useful for the teachers and educational managers to investigate students' opinions on the issue.

Soft skills can be advanced through the productive method of foreign language teaching, that is teachers can apply productive activities using the EMI concept to facilitate communication, management, and professional skills development. The study shows that for this purpose the case study, problem-based learning and essay writing can be used. Using the productive method, the authors designed the technology of soft skills development in engineering foreign language education. This technology includes usage of the case study, problem-based learning, and essay writing tasks, as well as the stages of their implementation. In addition, the authors developed the assessment criteria for the three groups of soft skills being mastered with the productive method of foreign language teaching, which is useful for foreign language teachers.

Having applied this technology in the experimental training of second-year engineering students, we discovered that in the experimental group, the low level of soft skills on the initial stage decreased up to $57 \%$ on the final stage, the middle level raised up to $39 \%$ and the high level improved up to $18 \%$, showing the efficiency of the technology used. Comparing the results of the experimental and control groups, it can be mentioned that on the initial stage, their levels were almost the same, while after using productive activities to master the soft skills of engineering students of the experimental group, we see that the difference at the final stage is significant.

Moreover, to critically analyse the findings obtained, the authors carried out the data analysis using the T-statistics that showed the statistically significant difference in the level of students' soft skills development between the participants of the experimental and control groups according to the results obtained during the initial and final stages of the experiment. Consequently, utilising the productive method of foreign language teaching leads to an increase of not only the command of foreign language communicative competence, but also the level of soft skills development, thus it can be used for soft skills development in engineering foreign language education.

Author Contributions: Conceptualization, O.D.M. and A.V.R.; methodology, O.D.M. and A.V.R.; software, O.D.M.; validation, O.D.M.; formal analysis, O.D.M.; investigation, O.D.M. and A.V.R.; resources, O.D.M. and A.V.R.; data curation, A.V.R.; writing-original draft preparation, O.D.M.; writing-review and editing, A.V.R.; visualization, O.D.M.; supervision, A.V.R.; project administration, A.V.R.; funding acquisition, A.V.R. All authors have read and agreed to the published version of the manuscript.

Funding: This research was funded by RFBR, grant number 20-313-90011.

Institutional Review Board Statement: Not applicable.

Informed Consent Statement: Informed consent was obtained from all subjects involved in the study.

Conflicts of Interest: The authors declare no conflict of interest.

\section{References}

1. Florea, R.; Stray, V. The skills that employers look for in software testers. Softw. Qual. J. 2019, 27, 1449-1479. [CrossRef]

2. Azmi, A.N.; Kamin, Y.; Noordin, M.K. Competencies of Engineering Graduates: What are the Employer's Expectations? Int. J. Eng. Technol. 2018, 7, 519-523. [CrossRef]

3. Dubey, R.S.; Tiwari, V. Operationalisation of soft skill attributes and determining the existing gap in novice ICT professionals. Int. J. Inf. Manag. 2020, 50, 375-386. [CrossRef]

4. Yarkova, T.A.; Cherkasova, I.I. Forming Soft Skills of Students in the Implementation of Professional Standard of a Teacher. Tyumen State Univ. Herald. Humanit. Res. 2016, 2, 222-234. [CrossRef] 
5. Bogdan, E.S. The development of soft skills as an important component of forming competencies of competitive graduates in the field of engineering. Eurasian Sci. J. 2019, 3, 1-8.

6. Capretz, L.F.; Ahmed, F. A call to promote soft skills in software engineering. Psychol. Cogn. Sci. Open J. 2018, 4, e1-e3. [CrossRef]

7. Triyanto, A. Development of Student Soft Skills in Learning Process. Adv. Soc. Sci. Educ. Humanit. Res. 2020, 436, 789-792. [CrossRef]

8. Häfner, P.; Häfner, V.; Ovtcharova, J. Teaching Methodology for Virtual Reality Practical Course in Engineering Education. Procedia Comput. Sci. 2013, 25, 251-260. [CrossRef]

9. Mamleeva, A. Developing Soft Skills And Critical Thinking. In Proceedings of the 18th Professional Culture of the Specialist of the Future (PCSF 2018), St. Petersburg, Russia, 28-30 November 2018. [CrossRef]

10. Kumar, G.; Sharma, V. Emotional Intelligence through Soft Skills for Employability. In Proceedings of the International Conference on Advancements in Computing \& Management (ICACM 2019), Jaipur, India, 5 October 2019. [CrossRef]

11. Lozovoy, A.Y.; Zashchitina, E.K.; Nazvanova, I.A. Students' soft skills as a factor of their professional competitiveness improvement. In Proceedings of the 2019 XVIII Russian Scientific and Practical Conference on PTES, St. Petersburg, Russia, 20-21 November 2019; pp. 82-85. [CrossRef]

12. Bishop, D.T. The hard truth about soft skills. Muma Bus. Rev. 2017, 1, 233-239. [CrossRef]

13. Rubtsova, A. Socio-linguistic innovations in education: Productive implementation of intercultural communication. IOP Conf. Ser. Mater. Sci. Eng. 2019, 497, 012059. [CrossRef]

14. Bylieva, D.; Bekirogullari, Z.; Kuznetsov, D.; Almazova, N.; Lobatyuk, V.; Rubtsova, A. Online group student peer-communication as an element of open education. Future Internet 2020, 12, 143. [CrossRef]

15. Zueva, I. Management Students' "Soft Skills" in Foreign Language Training at Technical University. SHS Web Conf. 2019, 69, 00144. [CrossRef]

16. Karimova, N. Soft Skills Development in Higher Education. Univ. J. Educ. Res. 2020, 8. [CrossRef]

17. Deep, S.; Ahmed, A.; Suleman, N.; Abbas, M.; Naza, U.; Shaheen, H.; Razzaq, A. The Problem-Based Learning Approach towards Developing Soft Skills: A Systematic Review. Qual. Rep. 2020, 25, 4029-4054. [CrossRef]

18. Tevdovska, E.S. Integrating soft skills in higher education and the EFL classroom: Knowledge beyond language learning. SEEU Rev. 2016, 11, 97-108. [CrossRef]

19. Odinokaya, M.; Andreeva, A.; Mikhailova, O.; Petrov, M.; Pyatnitsky, N. Modern aspects of the implementation of interactive technologies in a multidisciplinary university. E3S Web Conf. 2020, 164, 12011. [CrossRef]

20. Volkova, N.; Zinukova, N.; Vlasenko, K.; Korobeinikova, T. Soft skills, their development and mastering among post graduate students. SHS Web Conf. 2020, 75, 04002. [CrossRef]

21. Odinokaya, M.; Karpovich, I.; Mikhailova, O.; Piyatnitsky, A.; Klímová, B. Interactive technology of pedagogical assistance as a means of adaptation of foreign first-year students. IOP Conf. Ser. Mater. Sci. Eng. 2020, 940, 012130. [CrossRef]

22. Nugraha, N.; Purnamasari, I. Building Student Soft Skill Ability through Cooperative Learning. Adv. Econ. Bus. Manag. Res. 2019, 65, 8-12. [CrossRef]

23. England, T.K. Using collaborative learning to develop students' soft skills. J. Educ. Bus. 2020, 95, 106-114. [CrossRef]

24. Batsunov, S.; Derecha, I.; Kungurova, I.; Slizkova, E. Modern determinants of the soft skills development. E-koncept 2018, 4, 198-207.

25. Raitskaya, L.; Tikhonova, E.; Balykhin, M. What is behind soft skills? Perceptions and stances of university lecturers and students in Russia. SGEM Soc. Sci. Arts Conf. 2018, 5, 927-935.

26. Odinokaya, M.; Krepkaia, T.; Sheredekina, O.; Bernavskaya, M. Self-regulation as a basic element of the professional culture of engineers. Educ. Sci. 2019, 9, 200. [CrossRef]

27. Dragomir, I.; Niculescu, B. Different Approaches to Developing Writing Skills. Land Forces Acad. Rev. 2020, 25, 201-206. [CrossRef]

28. Bylieva, D.; Lobatyuk, V.; Safonova, A. Online forums: Communication model, categories of online communication regulation and norms of behavior. Humanit. Soc. Sci. Rev. 2019, 7, 332-340. [CrossRef]

29. AL-Ghazo, A.; Al-Zoubi, S.M. How to Develop Writing Skill through Constructivist Design Model. Int. J. Bus. Soc. Sci. 2018, 9, 91-98. [CrossRef]

30. Herţeg, C. Developing writing skills to engineering students. Ann. Univ. Apulensis Ser. Philol. 2012, 29-36. Available online: https://www.researchgate.net/publication/311705009_Developing_Writing_Skills_to_Engineering_Students (accessed on 31 May 2021).

31. Almazova, N.; Bylieva, D.; Lobatyuk, V.; Rubtsova, A. Human behavior as a source of data in the context of education system. In Proceedings of the International SPBPU Scientific Conference on Innovations in Digital Economy (SPBPU IDE 2019), St. Petersburg, Russia, 24-25 October 2019. [CrossRef]

32. Karpovich, I.A.; Krepkaia, T.N.; Voronova, L.S.; Combarros-Fuertes, P. Novice university educators: Professional, psychological and motivational spheres of adaptation. IOP Conf. Ser. Mater. Sci. Eng. 2020, 940, 012136. [CrossRef]

33. Medvedeva, O. Monitoring of Students' Soft Skills Development Within Foreign Language Learning Using Online Technologies. In Proceedings of the International Scientific Conference-Digital Transformation on Manufacturing, Infrastructure and Service (SPBPU DTMIS'20), St. Petersburg, Russia, 18-19 November 2020. [CrossRef]

34. Federal State Educational Standard of Higher Education. Available online: http:/ / fgosvo.ru/fgosvo/151/150/24 (accessed on 10 February 2021). 
35. Hüttner, J. Occupying a new space: Oral language skills within the disciplines in English medium instruction. In Rethinking Directions in Language Learning and Teaching at University Level; Loranc-Paszylk, B., Ed.; Research-publishing.net: Voillans, France, 2019; pp. 5-26. [CrossRef]

36. Bukve, T. Students' perspectives on English medium instruction: A survey-based study at a Norwegian university. Nord. J. Engl. Stud. 2018, 17, 215-242. [CrossRef]

37. Kennedy, J. Students vs. Language: Challenges faced by the undergraduates offering English medium instruction in Sri Lanka. People Int. J. Soc. Sci. 2017, 3, 554-566. [CrossRef]

38. Council of Europe. Common European Framework of Reference for Languages: Learning, Teaching, Assessment 2020-Companion Volume, Council of Europe Publishing, Strasbourg. Available online: www.coe.int/lang-cefr (accessed on 15 February 2021). 